\title{
The Ontario nuclear power dispute: a strategic analysis
}

Motahareh Armin ${ }^{1}$, Keith W Hipel ${ }^{1,2^{*}}$ and Mitali De ${ }^{3}$

\begin{abstract}
Background: The Graph Model for Conflict Resolution methodology is used to formally investigate the nuclear power dispute that took place in the Canadian province of Ontario in order to obtain strategic insights into its resolution. This flexible systems methodology is used to study the nuclear conflict at two key points in time, 2008 and 2010.

Results: The results of the 2008 analysis show that the only decision makers involved in the conflict who hold real power are the Federal and Ontario governments, although at the beginning of the investigation other organizations had also been considered as participating decision makers. According to a strategic analysis carried out for the conflict as it existed in 2010, the equilibria or potential resolutions of the 2008 analysis are found to be transitional states leading to the 2010 resolution. Moreover, a negative attitude by the Federal Government can cause an outcome to occur that is not highly preferred by either the Federal Government or the province of Ontario.
\end{abstract}

Conclusions: By closely following the decision makers' actions, a detailed analysis of the nuclear dispute in Ontario is carried out. Stability, sensitivity, and attitude analyses are performed, and the results are closely correlated with what happened in reality.

Keywords: Ontario nuclear power dispute, Graph model for conflict resolution

\section{Background}

The conflict between the Federal Government of Canada and the Ontario Provincial Government has been ongoing for the past couple of years. The Ontario Government intends to expand the Darlington nuclear site and plans to procure its reactors from Atomic Energy of Canada Limited (AECL), the company responsible for the building, maintenance, and management of CANDU (CANada Deuterium Uranium) Canadian reactors.

Meanwhile, the Federal Government announced the decision of restructuring and selling or privatizing AECL. Nuclear technology has been very important to Canada since its genesis. Huge investments have been made in this industry by the Federal Government of Canada over the years. If AECL is sold and the Ontario

\footnotetext{
* Correspondence: kwhipel@uwaterloo.ca

'Department of Systems Design Engineering, University of Waterloo,

Waterloo, Ontario N2L3G1, Canada

${ }^{2}$ Centre for International Governance Innovation, Waterloo, Ontario N2L 6C2, Canada

Full list of author information is available at the end of the article
}

Government does not buy its reactors from this company, it is very possible that no other province will make any purchases from AECL in the future.

CANDU reactors use a technology that is unique among other reactors in the world, and their safety standards are very strict. On March 11, 2011, an earthquake and tsunami occurred in Japan and caused serious damage to the reactors in the affected region. One of the main issues regarding Japanese reactors is that they emit radioactive water, whereas in the CANDUs, the steam and water in the secondary loops are not radioactive. Therefore, in a critical event, when heat release is required, the water in the secondary loop can be let out with no damage to the environment, and new clean water can be used. The other difference is that unlike Japan, all CANDUs are located in areas where tsunamis may not affect them, and environmental factors are taken into careful consideration in the design of CANDU reactors as well as advanced versions thereof (Canadian Nuclear Safety Commission, 2011).

\section{Springer}


CANDU technology is a unique treasure to Canada. It would be a disaster for Canada to miss the opportunity of pioneering this exclusive heavy water CANDU technology as well as other versions of its reactors. Experts believe that whatever rearrangements in AECL management take place, the involved parties have to make sure that AECL remains a Canadian-owned company, or else Canada will forfeit this historic opportunity for leadership in nuclear technology, as occurred in the aircraft industry when Canada's Avro Arrow aircraft technology was destroyed (Hipel and Bowman, 2011). Considering the importance of this technology and the conflict over the Canadian nuclear industry, the key purpose of this research is to model the aforementioned conflict by using the Graph Model for Conflict Resolution (GMCR) methodology. This approach realistically models the conflict between two or more players having different options under their control and preferences over what could take place. This academic work is helpful to researchers who would like to have an enhanced strategic understanding of the energy situation in Canada. Moreover, since the analyzed conflict is still an ongoing dispute in Canada, this study could be useful to decision makers and stakeholders involved in the dispute. Following an explanation of the history of the nuclear dispute, the dispute is modelled and analyzed for the situations existing in the years 2008 and 2010. The evolution of the dispute over time, the influence of attitudes on the potential resolution of the 2010 conflict, and other strategic insights are discussed. The application of GMCR to this specific dispute constitutes the first application of this kind of game theory technique to the Ontario nuclear dispute. In the next step, the conclusions are discussed, and finally, the methodology is explained.

\section{Results and discussions}

In this section, a brief introduction to the conflict is provided and the conflict in 2008 and 2010 are discussed, and the results are explained.

\section{Introduction to the conflict}

In this paper, the Canadian nuclear conflict is modeled with respect to two points in time. The first analysis was conducted in 2008. This issue is an ongoing problem, and the conflict has not been resolved. Since the first analysis, some other related announcements and news items have been published. Therefore, a second analysis was performed in 2010, taking into consideration the more recent information. Although the two analyses (ultimately) involve similar decision makers (DMs) and options, they are different in terms of the relative preferences of the DMs. In each analysis, the DMs and their options are introduced. After the feasible and indistinguishable states are determined, the relative preferences for each DM are defined. Then, static analysis and other dynamic analyses are performed.

Canada has twenty-two CANDU reactors; twenty of them are located in Ontario, the most populous province, one in Quebec, and one in New Brunswick. Nuclear energy provides about 15 percent of Canada's electricity (AECL, 2008).

In the coming decades, the Liberal Government of Ontario wants nuclear plants to remain the source of half of Ontario's electricity supply. It plans to install two new nuclear reactors, which will provide up to 3,200 megawatts of electricity, and to expand the Darlington nuclear site, in order to address the increasing demand for electricity as well as to reduce greenhouse gas (GHG) emissions. Although Dalton McGuinty, the Ontario Premier, in his election campaign had promised to shut down four coal-fired plants, which are highly polluting, by 2007, in 2006, he decided to postpone this plan to 2014, because there was no proper replacement energy producer (CBC News, 2006). At the beginning of March 2008, Energy Minister Gerry Phillips officially announced that the provincial government was seeking proposals to build a new nuclear plant. He declared that construction should begin in 2012 and electricity should be generated by July 1, 2018 (Benzie and Black, 2008). Organizations that submitted their proposals included AECL, Westinghouse Electric Co. LLC, an American company, and Areva, a French company (Frame, 2008).

As mentioned before, this conflict is analyzed with respect to two different points in time. In the following section, the dispute is explained according to the analyst's information and available publications as of 2008 . It is worth noting that the present time in the following section refers to the year 2008 .

\section{AECL's reputation}

Some incidents have aggravated the position of AECL in this bidding competition and may prevent the Ontario Government from selecting this company as the builder of the new plant reactors.

1) The National Research Universal (NRU) Chalk River reactor is the only nuclear reactor in North America that supplies medical isotopes for molecular imaging, radio therapeutics, and analytical instruments. On November 18, 2007, the Canadian Nuclear Safety Commission (CNSC) ordered the shutdown of the reactor, because it found that AECL had been operating the reactor for 17 months without a backup emergency power system for cooling pumps, which prevent the reactor core from melting down. In 2006, AECL was ordered by CNSC to upgrade the NRU by installing that system. After two weeks of shutdown, Michael Burns, the chairman of AECL at 
the time, resigned and Stephen Harper, the Prime Minister of Canada, accepted his resignation and blamed the Liberal-appointed CNSC for the closure. He pushed an emergency measure through Parliament on December 12, 2007, but the Liberals opposed the measure. The Liberals feared that the NRU was unsafe and required more upgrades. Eventually, the reactor was restarted in late January 2008, when Harper fired Linda Keen, the CNSC's head, who was a Liberal committee member. The outage created a critical and worldwide shortage of the radioactive diagnostic material and is considered a serious negative point in AECL's history (CBC News, 2008; Spears, 2008; Nathwani, 2009).

2) On May 16, 2008, AECL abandoned its plans to complete Multipurpose Applied Physics Lattice Experiment (MAPLE) reactors, which had been started in 1996. These reactors were to serve as a replacement for the NRU at Chalk River. In 2008, the project was millions of dollars over budget and eight years behind schedule. The failure of the MAPLE reactors is a dark point for AECL and has undermined its reputation. As a result of the failure of this project, at the beginning of June 2008, MDS Inc. launched a $\$ 1.6$ billion lawsuit against AECL (Akin, 2008; Hamilton, 2008b). Moreover, in an expert panel report commissioned by Prime Minister Harper, Goodhand et al. (2009) recommended that a completely new and more flexible isotope reactor be constructed.

3) The safety standards are another problem. After September 11, 2001, the International Atomic Energy Agency (IAEA) established guidelines mandating that reactor builders redesign reactors so that they have the ability to withstand a massive outside shock or explosion. These safety standards must be applied to all new reactor designs. As AECL's reactors do not meet these standards, new regulations could be a major setback for AECL. Jerry Hopwood, vice-president of reactor development at AECL, has accepted the design weaknesses, stating that they would design an advanced CANDU 6 or adapt the old one if needed, to meet the standards ${ }^{\text {a }}$ (Hamilton, 2007).

\section{The federal Government's view towards AECL}

In light of the problems pertaining to AECL, the Federal Government wants to enhance its nuclear credibility. Gary Lunn, Natural Resources Minister at the time, said that it is "imperative" that Ontario purchase new reactors from AECL (Geddes, 2007). Although Harper's government comprehends the importance of AECL as a federal Crown corporation, it does not completely support AECL's efforts to regain its previous reputation.
Harper's government has declared that in order to fulfill the country's growing electricity demands and facilitate the development of Canadian nuclear technology, the government has to decide about AECL's current status. The Conservatives are looking at different business models for AECL, including the sale of ownership stocks to one of several companies that have expressed interest, such as Westinghouse Electric Co. and France's Areva, foreign companies, and Bruce Power Inc., a Canadian company. Natural Resources Minister Lunn said that AECL's status is under review, stating that they are considering all options, from the status quo to a partnership with private investors to a sale to a foreign government. Another incentive for the Federal Government to change the status of AECL is the reliance of AECL's development program on federal tax dollars. Since, as mentioned above, AECL has incurred budget overruns, the sale of its stocks to a private company could alleviate taxpayers' criticisms of the Federal Government. On the other hand, industry observers say the lawsuit pertaining to the MAPLE reactors will make it more difficult for Ottawa to find a private suitor for AECL. This increases the probability that the government will opt to sell AECL to a foreign company or government (Hamilton, 2008b; Puxley, 2007). However, AECL does not want to be privatized. Its spokesman, Dale Coffin, disputed suggestions that AECL needs a strategic private-sector partner to compete in the world.

\section{The Federal Government vs. The Ontario Government}

On the other side of the conflict, the Ontario Government is dealing with its own issues. Premier McGuinty stated: "The Ontario Government is unwilling to purchase new reactors from AECL unless it receives assurance that the Federal Government will remain the ultimate backer of AECL". The McGuinty government is concerned about AECL's history and has made it clear that while it would prefer to buy home-grown technology, it is open to purchasing from a foreign company if it means getting the best deal for Ontario's taxpayers. If Ottawa does not support AECL, it will be very hard for it to sell the reactors in Ontario, and if it cannot do so, it will face a difficult time selling them anywhere else in the world (Hamilton, 2007).

In addition, timing and financial issues affect the Liberal Government's decision. McGuinty has promised to shut down all the province's coal-powered plants by 2014. New nuclear plants would be completed by 2018 if everything goes according to schedule. Furthermore, construction of a nuclear plant requires huge investments and compels Ontario's taxpayers to bear a heavy tax burden. Therefore, the Ontario Government wants AECL to be fully financially supported by the Federal Government. The provincial government is in an urgent 
situation in terms of the need for new power generation. It is unable to wait a very long time for AECL to prove its qualifications, but has to make its decision by March 2009 at the latest (Hamilton, 2008b; McParland, 2008).

\section{Green groups of Canada}

The Green Party of Canada, along with other green organizations and environmental groups, and the New Democratic Party (NDP) of Canada are on the other side of the conflict. They have always opposed the use of nuclear energy and believe that the Federal Government does not invest sufficiently in renewable energies. They think Canada has enough clean energy resources and does not need nuclear plants. These groups do not consider nuclear energy a clean energy, because there is still no proper means of nuclear waste management. They express their disagreement through their websites, articles, and speeches. Green groups are also concerned about the costs and consider nuclear energy generation to be expensive. Hence, in this dispute, green groups would agree with privatizing or selling AECL, as there would then be no need for the Federal Government to spend much money on AECL's funding, and taxpayers will not suffer. It would furthermore be easier for green groups to oppose AECL as a private nuclear organization, as it would not have governmental support (New Democratic Party, 2008; Sierraclub, 2008; Harris, 2008).

\section{Analysis in 2008}

\section{The state of the conflict in 2008}

AECL is in trouble; it has not sold a single reactor in ten years (by 2008). A new president was appointed in December 2007 to change the situation and return it to its once leading position in the nuclear industry. In the February federal budget, it received an appropriation of $\$ 300$ million to support research and develop new technology. However, AECL still cannot convince the Ontario Government to buy its advanced reactors. A few key factors can possibly change AECL's situation. In June 2008, AECL announced that it had signed an agreement with the Nuclear Power Institute of China to collaborate on the "design, research, development, and demonstration" of "low uranium consumption CANDU technologies". Moreover, AECL is working with South Korea on a process called "direct use of spent pressurized water reactor fuel in CANDUs" (DUPIC). DUPIC is unique and can give Canada the opportunity to solve many problems in a nuclear energy market increasingly dominated by light-water reactors. DUPIC also gives existing and new CANDU 6 reactors a chance to minimize the environmental risks. As nuclear experts point out, the existence of the DUPIC project alone gives the Federal Government a new option to give AECL another chance. It could be a point of strength for the company.
If AECL accomplishes good results with these projects and keeps achieving satisfactory contracts, it might change the Federal and Provincial Governments' views (Hamilton, 2008a).

Different parties and groups in Canada are concerned about AECL's future. Ontario Energy Minister Duncan believes that AECL would be worth far less if Ottawa privatized it. If AECL were sold to a foreign company, thousands of skilled workers would lose their jobs at a time when the province has already lost thousands of industrial jobs.

\section{Decision makers, options, states and relative preferences}

According to the background of the conflict, the DMs of the dispute are listed below:

- The Federal Government

- The Ontario Government

- AECL

- Green Groups

Hereinafter, FG, OG, and GG denote Federal Government of Canada, Ontario Government, and Green groups, respectively.

The four aforementioned DMs and their options, and the current state of the conflict are shown in Table 1. In order to better represent and discriminate states, each state is defined as follows:

$s_{i}=\left(x_{1} x_{2} x_{3}, x_{4} x_{5}, x_{6}, x_{7}\right), \quad x_{j} \in\{Y, N\}, \quad j=1,2, \ldots, 7$,

where $x_{1} x_{2} x_{3}$ are the options that belong to FG, $x_{4} x_{5}$ belong to OG, $x_{6}$ belongs to AECL, and $x_{7}$ belongs to GG. In addition, $x_{j}=Y$ indicates that the $j$-th option is chosen and $x_{j}=N$ indicates that it is not. It is a large conflict, so GMCR II software developed by the Conflict Analysis Group in the Department of Systems Design Engineering at the University of Waterloo (Fang et al., 2003a,b; Hipel et al., 1997) was used to perform various types of analyses.

The infeasible states are also determined. These states must be eliminated from the analysis. A number of infeasible states are observed in this conflict, and after removing those states, 48 states remain.

- The options of the Federal Government and the Ontario Government are mutually exclusive. Therefore, considering the options mentioned in Table 1, the states listed below should be removed:

- Federal Government: (Y Y -, - -, -, -), (Y - Y, - -, $-,-)$, and (- Y Y, - -, -, -)

- Ontario Government: (- - -, Y Y, -, -) 
Table 1 DMs and options in 2008 analysis

\begin{tabular}{|c|c|c|}
\hline DMs & Options & $\begin{array}{c}\text { Status } \\
\text { Quo }\end{array}$ \\
\hline \multirow[t]{3}{*}{ Federal Government (FG) } & $\begin{array}{l}\text { 1. Sell less than } 50 \% \text { of AECL's } \\
\text { stocks, and keep control of it }\end{array}$ & $\mathrm{N}$ \\
\hline & 2. Sell or privatize AECL & $\mathrm{N}$ \\
\hline & 3. Fully support AECL & $\mathrm{N}$ \\
\hline \multirow[t]{2}{*}{ Ontario Government (OG) } & 4. Buy reactors from $A E C L$ & $\mathrm{~N}$ \\
\hline & $\begin{array}{l}\text { 5. Buy reactors from a foreign } \\
\text { company }\end{array}$ & $\mathrm{N}$ \\
\hline $\mathrm{AECL}$ & $\begin{array}{l}\text { 6. Convince both governments } \\
\text { that it is capable of fulfilling its } \\
\text { mandates }\end{array}$ & $\mathrm{N}$ \\
\hline Green Groups (GG) & $\begin{array}{l}\text { 7. Continue their protests against } \\
\text { nuclear power }\end{array}$ & Y \\
\hline
\end{tabular}

Based on the background study of the conflict, the preferences of the three DMs are determined using the option prioritizing method (Explained in Methods). Some explanations are provided and used to form the relative preferences.

- The Federal Government (FG) is contemplating the future of AECL: To sell less than 50\% of AECL, sell it all or privatize it, or support it. However, its negotiations are not clear to other parties and to the public. The Federal Government prefers AECL reactors be sold to Ontario, so that AECL can gain credit to sell more reactors to other countries.

After the states presenting this situation, the Federal Government next prefers the states in which neither the Federal nor the Ontario Government take any action. The Federal Government would prefer to sell AECL if it is faced with complaints from taxpayers or the Ontario Government. The least favoured states for this DM are the ones that represent the support of AECL by the Federal Government. Table 2 demonstrates the specific way that state prioritization is managed in GMCR II for FG. In this table, preference statements are listed from most important at the top to least important at the bottom. The numbers in the left column of Table 2 refer to the option numbers given in Table 1, where a negative sign means that the option is not taken. Notice that the most important preference for the Federal Government is not to fully support AECL by not taking option 3 (denoted by -3 ). Assuming transitive or ordinal preferences, an algorithm can take the prioritized preference statements of the Federal Government in Table 1 and rank the states from most to least preferred where ties are allowed.

- The Ontario Government (OG) most prefers to select home-grown technology if AECL is successful
Table 2 The option prioritization table for the Federal Government (FG)

\begin{tabular}{ll}
\hline Preference Statements & \multicolumn{1}{c}{ Explanation } \\
\hline-3 & $\begin{array}{l}\text { The most important thing for FG is not to } \\
\text { support AECL, and not to invest more } \\
\text { money into it. }\end{array}$ \\
\hline 2 & Next, FG prefers to privatize AECL. \\
\hline$-1 \&-2 \&-3 \& 4$ & $\begin{array}{l}\text { FG mostly prefers that OG buys its reactors } \\
\text { from AECL. }\end{array}$ \\
\hline$-1 \&-2 \&-3 \&-4 \&-5$ & $\begin{array}{l}\text { It prefers that both governments take } \\
\text { no action. }\end{array}$ \\
\hline $2 \& 4$ & $\begin{array}{l}\text { Next, it prefers to privatize AECL and prefers } \\
\text { OG to buy its reactors from AECL. }\end{array}$ \\
\hline $1 \& 4$ & $\begin{array}{l}\text { Next, it would like to sell less than half of } \\
\text { AECL's stocks and OG to buy its reactors } \\
\text { from AECL. }\end{array}$ \\
\hline $3 \& 4 \&-5$ & $\begin{array}{l}\text { After that, it prefers the case that it supports } \\
\text { AECL, and OG buys its reactors from AECL. }\end{array}$ \\
\hline $3 \&-4 \&-5$ & It next prefers the situation in which it \\
& supports AECL, and OG waits. \\
\hline$-1 \&-2 \&-3$ if 5 & $\begin{array}{l}\text { If OG makes a foreign purchase, FG prefers } \\
\text { to do nothing. }\end{array}$ \\
\hline 6 & $\begin{array}{l}\text { Redesigning the reactors by AECL is one } \\
\text { of its least priorities. }\end{array}$ \\
\hline-7 & $\begin{array}{l}\text { AECL working on the DUPIC project is also } \\
\text { of less importance for FG. }\end{array}$ \\
\hline
\end{tabular}

in the redesign process. In addition, it would prefer that the Federal Government supports AECL. AECL being supported by FG is much more important to OG than redesigning CANDU reactors. It expects the Federal Government to support AECL in completing its projects on schedule. Next, it prefers the future of AECL to be resolved and to buy reactors from this company when AECL is trusted. As the Ontario Government does not want to waste time, it would rather purchase reactors from a foreign company if the future of AECL is undetermined.

- AECL is trying to complete its projects in order not to be sold. The most desirable states for AECL are the ones in which AECL is not sold. Among these states, it is more preferable for AECL to be supported, and it is also very important for AECL to sell its reactors to the Ontario Government.

- Green Groups (GG) are against nuclear energy. They declare their opposition via speeches and websites.

\section{Static analysis}

The equilibrium states (along with their corresponding stability types) determined by running the stability analysis in GMCR II are listed horizontally as:

- (N Y N, N N, N, Y): state 27, GMR, SMR, 
- (N Y N, N N, Y, Y): state 39, GMR, SMR, and

- (N Y N, Y N, Y, Y): state 43, Nash, GMR, SMR, SEQ.

These states indicate what actually took place in reality. State 43 is the most stable equilibrium state, as its stability type is Nash, which also means that state 43 is equilibrium according to SEQ, GMR, and SMR. Because 43 is Nash equilibrium, no DM can unilaterally move to a more preferred state from state 43 . States 27 and 39 are also equilibria in this conflict, but only according to SMR and GMR stability, which means sanctioning DMs can move to less preferred states when blocking the given DM's unilateral improvement, which is a movement by a DM to a more preferred state. What happened in reality (as of 2010) is that the Ontario Government chose AECL as the vendor of the reactors, and then the Federal Government decided to attempt to privatize AECL. After this decision was made, the Ontario Government postponed the purchase of the two reactors, because the future of AECL was very uncertain. Therefore, the state that took place was state 43 , but states 27 and 39, which can be presented as (N Y N, Y $\mathrm{N}, \mathrm{N}-, \mathrm{Y})$, happened after state 43 , where a dash means Y or N. Also, since states 27 and 39 are only GMR and SMR equilibria, the stability of these states is not as strong as an SEQ equilibrium in which the sanctions by other DMs against unilateral improvements by a focal DM can only be levied using unilateral improvements. Here, one may conclude that neither state 27 nor state 39 are the final equilibria of the conflict, so the dispute will not finish at this point.

\section{Status Quo analysis}

To apply status quo analysis, the current state of the conflict has to be determined. Next, the analyst investigates the way the conflict has evolved from its initial state in 2008. In the current state of the conflict, FG and OG are not taking any action; AECL is working on the DUPIC project and on the design of Advanced CANDU Reactors (ACRs), and consequently, trying to satisfy its customer, OG, and its owner, FG (option 7); and GG is protesting. This set of options represents the status quo state $25(\mathrm{~N} \mathrm{~N} \mathrm{~N}, \mathrm{~N} \mathrm{~N}, \mathrm{~N}, \mathrm{Y})$. In this case, the game develops from state $25(\mathrm{~N} \mathrm{~N} \mathrm{~N}, \mathrm{~N} \mathrm{~N}, \mathrm{~N}, \mathrm{Y})$ to states 43, 27 , and 39. The evolution of the conflict is shown in Table 3. In each level, one DM can move the conflict from the existing state to another state. The arrows, along with an assigned DM, show which DM is moving the conflict.

Although it is shown that the 2008 conflict will finish at states 27 and 39 (which is what happened in reality), later the authors show that in fact the conflict will again move to state 43 , and states 27 and 39 are the transition
Table 3 Evolution of the conflict

\begin{tabular}{|c|c|c|c|c|c|c|c|c|c|}
\hline \multicolumn{10}{|l|}{ Federal Government } \\
\hline $\begin{array}{l}\text { 1. Sell less than } 50 \% \\
\text { of AECL }\end{array}$ & $\mathrm{N}$ & & $\mathrm{N}$ & & $\mathrm{N}$ & & N & & $\mathrm{N}$ \\
\hline 2. Privatize AECL & $\mathrm{N}$ & & N & & $\mathrm{N}$ & $\begin{array}{l}\mathrm{FG} \\
\rightarrow\end{array}$ & Y & & Y \\
\hline 3. Support AECL & $\mathrm{N}$ & & N & & $\mathrm{N}$ & & N & & $\mathrm{N}$ \\
\hline \multicolumn{10}{|l|}{ Ontario Government } \\
\hline 4. Buy from $A E C L$ & $\mathrm{~N}$ & & N & $\underset{\rightarrow}{\mathrm{OG}}$ & Y & & Y & $\underset{\rightarrow}{\mathrm{OG}}$ & $\mathrm{N}$ \\
\hline $\begin{array}{l}\text { 5. Buy from a foreign } \\
\text { company }\end{array}$ & $\mathrm{N}$ & & $\mathrm{N}$ & & $\mathrm{N}$ & & N & & $\mathrm{N}$ \\
\hline \multicolumn{10}{|l|}{$\mathrm{AECL}$} \\
\hline 6. Satisfy FG and OG & $\mathrm{N}$ & $\begin{array}{c}\mathrm{AECL} \\
\rightarrow\end{array}$ & Y & & Y & & Y & & - \\
\hline \multicolumn{10}{|l|}{ Green Groups } \\
\hline \multirow[t]{2}{*}{ 7. Protest } & Y & & Y & & Y & & Y & & Y \\
\hline & 25 & & 37 & & 29 & & 43 & & $27 \& 39$ \\
\hline
\end{tabular}

states in the 2010 conflict. It should be noted that the number assigned to each state is not the same in the 2008 and 2010 conflicts.

\section{Sensitivity analysis}

In order to gain more insights, some sensitivity analyses have been run. Sensitivity analyses can help the analyst to have a better understanding of the conflict and the static analysis. For example, in this conflict, it seems that although the Green Groups, GG, have an option to protest against the investment in and the use of nuclear energy, they are not as powerful as the other three DMs. The main reason for this is that all the other DMs, in contrast to GG, are in favour of nuclear energy. It seems logical that the fourth DM, being the only anti-nuclear $\mathrm{DM}$, does not have a considerable effect on the result of the conflict. To see how much this anticipation is correct, GG is omitted from the game, and another static analysis is executed, and the equilibrium states are shown below:

- (N Y N, N N, N): state 3, GMR, SMR,

- (N Y N, N N, Y): state 15, GMR, SMR, and

- (N Y N, Y N, Y): state 19, Nash, GMR, SMR, SEQ.

These equilibria verify the aforementioned expectation, as the indicated results are essentially the same as the results in the previous analysis. Option prioritization tables show that the decision of GG regarding whether to protest or not is among the least important issues for all DMs except for GG. Therefore, the results show that GG is not an important DM in this conflict. In other words, GG cannot significantly influence the other DMs' decisions regarding the future of AECL. 
Another idea is to eliminate AECL as well. Although it might seem that AECL's attempt to obtain the trust of FG and OG would affect the decisions of those two DMs, it is possible that their decisions are independent of AECL's achievements. If this possibility is in fact true, AECL would not actually be a DM in the conflict, and only the two governments would be important DMs. Thus, if AECL were to be omitted from the analysis, and AECL is not a DM of any real consequence in the conflict, the two equilibria one would expect to obtain would be: (N Y N, Y N), which would be equivalent to

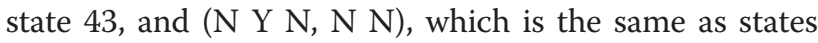
27 and 39. The related analysis results verify the fact that AECL is not an influential DM. The resulting equilibrium states for this analysis are shown below:

- (N Y N, N N): state 3, GMR, SMR,

- (N Y N, Y N): state 7, Nash, GMR, SMR, SEQ.

In order to more deeply investigate the effect of AECL as a DM on the results of the modeling, the preferences of this DM are changed. If AECL is not significantly affecting the game, changing its preferences should not change the equilibria regarding the future of this company. This change is applied to the game with three DMs, in which only GG is omitted. Different arrangements of AECL's relative preferences are made at this level. The results show that the equilibria do not change, although their types do with some changes in the relative preferences. Therefore, one may conclude that AECL does not, in fact, have a considerable effect on the other two DMs.

Finally, since only two DMs are found to be influential in this conflict, the status quo table is reproduced to show the evolution of this smaller conflict (Table 4).

\section{Analysis in 2010}

Previously, the Ontario nuclear dispute was analyzed for 2008. This dispute, however, is an ongoing conflict in the province. Therefore, in the following sections, an attempt is made to perform a new GMCR analysis of the

Table 4 Evolution of the 2-DM 2008 conflict

\begin{tabular}{|c|c|c|c|c|c|c|c|}
\hline \multicolumn{8}{|l|}{ Federal Government } \\
\hline 1. Sell less than $50 \%$ of $\mathrm{AECL}$ & $\mathrm{N}$ & & $\mathrm{N}$ & & $\mathrm{N}$ & & $\mathrm{N}$ \\
\hline 2. Privatize $\mathrm{AECL}$ & N & & $\mathrm{N}$ & $\begin{array}{c}\mathrm{FG} \\
\rightarrow\end{array}$ & $\mathrm{Y}$ & & $\bar{Y}$ \\
\hline 3. Support AECL & $\mathrm{N}$ & & $\mathrm{N}$ & & $\mathrm{N}$ & & $\mathrm{N}$ \\
\hline \multicolumn{8}{|l|}{ Ontario Government } \\
\hline 4. Buy from $A E C L$ & $\mathrm{~N}$ & $\stackrel{\mathrm{OG}}{\rightarrow}$ & Y & & Y & $\stackrel{\mathrm{OG}}{\rightarrow}$ & $\mathrm{N}$ \\
\hline \multirow[t]{2}{*}{ 5. Buy from a foreign company } & $\mathrm{N}$ & & $\mathrm{N}$ & & $\mathrm{N}$ & & $\mathrm{N}$ \\
\hline & 1 & & 5 & & 7 & & 3 \\
\hline
\end{tabular}

same conflict, but with an updated background. In addition, regarding energy issues in the province, the Government of Ontario has recently published an updated energy report (Ontario Government, 2010).

\section{Updated background of the conflict}

To summarize the history of the conflict in 2010, and to update the background of the dispute in 2008, the timeline of the nuclear project is described as follows (Ontario Government, 2009). In March 2008, the Ontario Government announced a two-phase competitive procurement process to choose a preferred nuclear reactor vendor. After holding a series of confidential meetings with the vendors in June 2008, Infrastructure Ontario announced that all three vendors that had submitted Phase 1 Proposal Submissions received 'satisfactory' ratings and would be invited to proceed to Phase 2 of the Request For Proposal (RFP). Subsequently, Infrastructure Ontario released Phase 2 of the Nuclear Procurement Project RFP. At this stage, and in November 2008, the first analysis was performed. From February to May 2009, all three respondents submitted Phase 2 Proposals, and the Government of Canada announced that it was proceeding with a restructuring of AECL. In June 2009, the Ontario Government announced that the Nuclear Procurement Project RFP was being suspended due to concerns about pricing and uncertainty regarding AECL's future.

The Centre for International Governance Innovation (CIGI) published an important report in November 2009. This report studies the nuclear industry in Ontario and briefly investigates the expansion of the Darlington nuclear site, the most important nuclear project in Canada. The report stated that by 2008, Ontario had planned to invest $\$ 40$ billion to replace and refurbish its nuclear generating capacity, and subsequently, in February 2009, bids to build a new facility at Darlington were accepted by the province (Cadham, 2009).

The CANDU design, proposed by AECL, is proudly Canadian in that Team CANDU represents the provider of Ontario's existing installed nuclear facilities. The AECL CANDU design was the only design to fully meet the requirements of Infrastructure Ontario among the three vendors, consisting of AECL, Areva Group and Westinghouse Electric Co. Hence, for this and other reasons, the province selected AECL's technology as the winner.

In July 2009, George Smitherman, the Energy Minister of Ontario, said that the government wanted to negotiate with Ottawa to reduce the bidding price. Smitherman declared that AECL's bid was "billions" above what Ontario had anticipated. Ontario Power Generation (OPG) had estimated the cost of the installation of the two ACRs at $\$ 3,000$ per kilowatt, compared to $\$ 10,800$, 
the price offered by AECL. One of the major reasons for the offer being this high is that the design of the ACR is not yet complete, but Ontario is disinclined to pay for the cost of the research and development (R\&D) process. On the other hand, before the offer was submitted by AECL, the Harper government had told the company that its bidding price must cover all the costs of R\&D, and that AECL should not count on future sales to put off the cost overruns. In the case in which the Federal Government decides to keep AECL as a federal Crown corporation and not sell it, the government needs to ensure that the Ontario nuclear project is commercialized in an attempt to preserve AECL's value and to avoid federal taxpayers subsidizing Ontario ratepayers (McCarthy and Howlett, 2009).

The AECL's restructuring is currently under scrutiny. In 2007, the Federal Government hired the National Bank to provide independent financial advice and to help find the best way to carry out the mandates of AECL. The National Bank put forward some solid recommendations. In its recommendations, it was suggested that AECL has two concurrent mandates: commercial goals involving the selling and servicing of reactors, and R\&D with regards to projects and technology. The bank advised that at least $51 \%$ of AECL be sold and encouraged the Government of Ottawa to improve AECL's standing in the international market. Natural Resources Canada published a report in May 2009 to present the ideas they received from the National Bank and other consultants. AECL's failure in handling its projects shows that in the past, the two opposing mandates have not worked well together, and AECL has fallen short on many of its objectives. Some of AECL's unsuccessful projects were mentioned above. The former Minister of Natural Resources, Lisa Raitt, advised: "The best chance to take advantage of this nuclear renaissance is to divide the two of them and seek global participation." Raitt suggested that the designing and building of reactors is very expensive, and Canadian taxpayers cannot shoulder this burden on their own, so AECL needs a strategic alliance in order to compete in the world (CTV, 2009). As stated in the project procurement, the Government of Canada announced the restructuring of AECL in May 2009. It also hired N.M. Rothschild \& Sons to provide financial advice and available options and received their financial analysis on the restructuring plan of AECL in October 2009, but the report is confidential due to commercial confidentiality considerations.

As stated by Raitt, the company's research-anddevelopment division, Chalk River laboratories, will continue to be government-owned, but with private-sector management (CBC News, 2009). The reactor business and its attractive maintenance and refurbishment activities would then be offered for sale on either a majority or minority ownership. Some parties accuse the government of wanting to sell AECL in order to balance its budget deficit. According to the former Minister of Natural Resources, however, this decision is about bolstering the industry. However, this reconstruction is not desired by the Ontario Government as stated by Smitherman: "The government of Canada needs to do the work that they are doing now to clarify the future ownership of AECL, and when they have clarified that, to sharpen their pencils substantially so that the people of the province of Ontario can renew their nuclear fleet with two new units from that company" (McCarthy and Howlett, 2009).

Having discussed the points of view of the two governments, it can be concluded that Ontario will not move until Ottawa clarifies AECL's ownership status. The other key issue is AECL's bidding price. Thus, the uncertain future of AECL and the high price were two important factors that led Ontario to postpone the project. According to the background information, it is nonetheless clear that Ontario mostly prefers to buy reactors from AECL.

The government of Canada, on the other hand, can decide between several options: privatizing and restructuring AECL, selling it to a Canadian or a foreign corporation, or keeping it public and consequently helping AECL to decrease the price. It has been a long time since the announcement of selling AECL, but it has not yet happened. Therefore, there is still the possibility that the government will not privatize the federal Crown corporation. Industry insiders say that the companies that are interested in partnership with AECL are an international company, US-based Westinghouse Electric Co., Canadian engineering giant SNC-Lavalin Group Inc., and Bruce Power, a Canadian-owned consortium that operates a nuclear station in Ontario. The bidding process closed on June 30, 2010 (The Globe and Mail, 2010). Sources close to negotiations say that only SNCLavalin Group Inc. and Bruce Power have submitted their bids to partner with AECL (McCarthy, 2010). What happened in reality was that in June 2011, the Ottawa government announced the sale of AECL to SNCLavalin Group Inc. (McCarthy, 2011).

Since there is opposition against selling or privatizing $\mathrm{AECL}$, this decision is not an easy one for the government to undertake (The Star, 2009). AECL possesses an internationally competitive reactor design and employs thousands of Canadian workers, and AECL's supporters argue that it is not beneficial for the governments to let this company be sold. Canadian nuclear analyst David Jackson says that the problem with dividing AECL into two parts and privatizing one of them is that "no potential purchaser would want to buy an ACR with no assured $R \& D$ backup and thus, in effect the 
restructuring is the end of ACR" (Cadham, 2009). On the other hand, the Federal Government's supporters believe that selling AECL is a sound decision as this company has been a burden on taxpayers for a long time and it has not been a cost-efficient investment. In addition, they think selling to a foreign company, rather than a Canadian company, would be a much better decision. A domestic sale will not change the pressure on taxpayers. Furthermore, selling AECL to a domestic buyer will not help the company to regain its reputation and become a competitive player in the international market (McCarthy, 2010).

There are also other provinces, such as New Brunswick and Saskatchewan, that have indicated an interest in buying new reactors. In July 2010, however, New Brunswick announced that it would not choose AECL as the provider of its reactors, and is instead turning to Areva Group, which is a company that was interested in buying AECL, but dropped out from the bidding. This decision, along with what happened in the Ontario contract, are considered major setbacks for AECL, and complicate the decision of the Federal Government regarding selling off AECL (The Globe and Mail, 2010). AECL was counting on the Darlington project to galvanize its huge resources to launch its new Advanced CANDU Reactor (ACR). Therefore, in the end, if Ontario, as the largest customer, decides not to buy any reactor at all, it would be unlikely that other provinces would consider AECL's unproven, first-of-its-kind ACR technology as a serious option.

The problem gets more complicated when one considers the massive amount of money that Ontario has spent on its nuclear industry. It operates more CANDU reactors than all of the other Canadian provinces or countries combined. Moreover, AECL has about 5000 employees, and privatizing it will lead to a large number of job losses, which is not desired by any of the DMs or the political parties in the country (McCarthy and Howlett, 2009).

\section{Decision makers, options, states and relative preferences}

In the 2010 analysis, there are only two DMs, the Federal and Ontario Governments. According to the updated background, neither AECL nor the Green Groups are important DMs. Consequently, their decisions do not affect the final decision that the Federal and Ontario Governments will make (Cadham, 2009). Since it is the responsibility of the Federal Government to financially support AECL, if this government does not provide sufficient funding for the company, the possibility that AECL can compete with its foreign rivals and win the contract becomes very low. The other DM that can seriously affect the outcome of the conflict and the future of AECL is the Ontario Government. Although AECL's suggested bidding price for the expansion of Ontario's nuclear power stations is very high, if the Ontario Government accepts AECL's offer, it is possible that AECL could remain as a public company. Regarding the DUPIC project, which AECL is working on, the published news and interviews of the officials of the two governments do not indicate that they pay much attention to the performance of AECL on this project. The Federal and Ontario Governments are more concerned about AECL's progress in building and selling reactors. Therefore, in the 2010 analysis, there are only two main DMs, the Federal Government and the Ontario Government. Regarding the options for the two governments, Table 5 shows the options for each DM. As can be seen, the options for each DM change with respect to the previous analysis in 2008, shown in the upper part of Table 1.

In the most recent analysis (2010), the first two options of the Federal Government change from what they were in 2008, since in 2010, it is determined that if the Federal Government decides to restructure AECL, it will privatize it, and not sell only less than half of its stocks. The options, however, are selling to a domestic or an international organization. The reason for this is that, in practice, the Federal Government is studying the privatization of one part, $R \& D$, and selling the other part, CANDU. The Ontario Government has the same options as in 2008. However, after examining the vendors' bids, the province recognized that if the final decision is to buy new reactors, the vendor would definitely be AECL, so its option to purchase reactors from a foreign company would be essentially eliminated. Taking into consideration the latest announcements and the updated background, as well as the options, the relative preferences of the DMs will also change.

Regarding the infeasible states, the options for the two DMs are mutually exclusive. The Federal Government cannot privatize and support AECL at the same time. Similarly, the Ontario Government cannot choose its two options simultaneously. Therefore, the following infeasible states are removed from the game, and 12 feasible states remain, which are shown in Table 6.

- FG: (Y Y -, - -), (Y - Y, - -), (- Y Y, - -)

- OG: (- - , Y Y)

Rather than using option prioritization to determine the relative preferences of the second DM, as was done

Table 5 DMs and options in 2010 Analysis

\begin{tabular}{ll}
\hline DMs & Options \\
\hline Federal Government & $\frac{\text { 1. Sell AECL (to a foreign company) }}{\text { 2. Sell AECL (to a Canadian company) }}$ \\
\hline Ontario Government & $\frac{\text { 3. Support AECL }}{\text { 4. Buy from a foreign company }}$ \\
\hline
\end{tabular}


in the previous analysis, direct ranking is employed whereby the states are ranked from most to least preferred by the analyst. This method works well for small conflicts, such as the small 12-state conflict considered here. In Tables 7 and 8, the ranking of states for the Federal and Ontario Governments are directly defined.

\section{Static analysis}

After defining the DMs, their options and preferences, static analysis is performed to investigate the final possible outcomes. States 1 and 11 are found to be the equilibria of the conflict. The equilibria in this case are shown below. It is worth noting that in order to find the equilibria, Sequential and Nash stability are considered.

- (N N N, N N): state 1, SEQ,

- (Y N N, N Y): state 11, Nash, GMR, SMR, SEQ.

It should be noted that by DMs being conservative, more states are stable, and the uncertainty of the game rises. In other words, if the DMs are very conservative, other concepts of stability should be considered. The reason for this is that if the DMs refrain from moving to different states on account of the possibility of losing benefits, the conflict will stop in more states and there will be more equilibria, compared with the situation in which the DMs accept the risks and move from one state to another. However, in this specific conflict the DMs are not conservative. As an example, more than a year ago, the Federal Government announced the restructuring AECL, but it has not yet sold it. In addition, Ontario Government announced AECL to be the best company, but postponed its decision about buying reactors from it. These examples show that the DMs do accept some risks and do move from state to state. Therefore, GMR and SMR stability concepts are ignored, and SEQ and Nash stability are being considered.

As of July 2011, what happened in reality was that the commercial reactor business of AECL was sold to SNCLavalin, a Montreal-based company. Specifically, on June 27, 2011, Ottawa announced the sale of the reactor

Table 6 List of feasible states

\begin{tabular}{|c|c|c|c|c|c|c|c|c|c|c|c|c|}
\hline Federal Government & & & & & & & & & & & & \\
\hline $\begin{array}{l}\text { 1. Sell AECL (to a } \\
\text { foreign company) }\end{array}$ & N & Y & $\mathrm{N}$ & $\mathrm{N}$ & N & Y & N & $\mathrm{N}$ & N & Y & N & N \\
\hline $\begin{array}{l}\text { 2. Sell AECL (to a } \\
\text { Canadian company) }\end{array}$ & N & N & Y & $\mathrm{N}$ & $\mathrm{N}$ & $\mathrm{N}$ & Y & $\mathrm{N}$ & N & $\mathrm{N}$ & Y & N \\
\hline 3. Support AECL & N & N & N & Y & $\mathrm{N}$ & $\mathrm{N}$ & N & Y & N & $\mathrm{N}$ & N & Y \\
\hline Ontario Governme & & & & & & & & & & & & \\
\hline $\begin{array}{l}\text { 4. Buy from a foreign } \\
\text { company }\end{array}$ & N & N & N & N & Y & Y & Y & Y & N & $\mathrm{N}$ & N & N \\
\hline 5. Buy from $A E C L$ & N & N & N & $\mathrm{N}$ & N & N & N & $\mathrm{N}$ & Y & Y & Y & Y \\
\hline State Number & 1 & 2 & 3 & 4 & 5 & 6 & 7 & 8 & 9 & 10 & 11 & 12 \\
\hline
\end{tabular}

Table 7 Direct ranking box in GMCR II for the Federal Government

\begin{tabular}{|c|c|c|c|c|c|c|c|c|c|c|c|c|}
\hline Federal Government & & & & & & & & & & & & \\
\hline $\begin{array}{l}\text { 1. Sell AECL (to a } \\
\text { foreign company) }\end{array}$ & $\mathrm{N}$ & Y & $\mathrm{N}$ & Y & N & N & Y & $N$ & $N$ & N & N & N \\
\hline & Y & N & $\mathrm{N}$ & $\mathrm{N}$ & Y & N & $\mathrm{N}$ & Y & $\mathrm{N}$ & N & N & $N$ \\
\hline 3. Support AECL & $\mathrm{N}$ & N & $\mathrm{N}$ & $N$ & N & N & $\mathrm{N}$ & $\mathrm{N}$ & $N$ & Y & Y & Y \\
\hline Ontario Government & & & & & & & & & & & & \\
\hline & $\mathrm{N}$ & N & $\mathrm{N}$ & $N$ & N & N & Y & Y & Y & N & N & Y \\
\hline 5. Buy from $A E C L$ & Y & Y & Y & $\mathrm{N}$ & N & N & $\mathrm{N}$ & $\mathrm{N}$ & $\mathrm{N}$ & Y & N & N \\
\hline State Number & 11 & 10 & 9 & 2 & 3 & 1 & 6 & 7 & 5 & 12 & 4 & 8 \\
\hline
\end{tabular}

business of AECL to this Canadian company for $\$ 15$ million. This change in ownership will cause a loss of jobs in Ontario: 1,200 out of about 2,000 employees at AECL's commercial division will move to the new CANDU Energy division of SNC-Lavalin in Quebec (Babbage, 2011; McCarthy, 2011). Although Ontario's decision to buy two new Enhanced CANDU 6 reactors has not yet been officially announced, the analysis results of this paper are in fact very close to what happened in the real world. In particular, state 11, the equilibrium of the conflict, represents the situation in which AECL is sold to a Canadian company (corresponding with SNCLavalin's ownership of CANDU Energy), and Ontario buys two new reactors from AECL.

Since this conflict is not very big, the static analysis can also be performed by hand without the software. The reachable list is shown in Table 9. In Table 10, the states are ranked from most to least preferred for each DM. The unilateral improvements are listed under each state for each DM. The type of stability for a given state and DM is written above the state in the ranking of states for the DM. In Table 10, the letters $r, s$, and $u$ stand for rational stability, sequential stability (SEQ), and unstable, respectively. When a state is stable for all of the DMs, it is an equilibrium indicated by E. Notice,

Table 8 Direct ranking box in GMCR II for the Ontario Government

\begin{tabular}{|c|c|c|c|c|c|c|c|c|c|c|c|c|}
\hline Federal Government & & & & & & & & & & & & \\
\hline $\begin{array}{l}\text { 1. Sell AECL (to a } \\
\text { foreign company) }\end{array}$ & $\mathrm{N}$ & $N$ & N & $Y$ & $\mathrm{~N}$ & $\mathrm{~N}$ & $Y$ & $\mathrm{~N}$ & $Y$ & $N$ & $N$ & $\mathrm{~N}$ \\
\hline & N & $N$ & Y & $\mathrm{N}$ & $\mathrm{N}$ & Y & $\mathrm{N}$ & Y & $\mathrm{N}$ & $\mathrm{N}$ & $\mathrm{N}$ & $N$ \\
\hline 3. Support AECL & Y & $N$ & $\mathrm{~N}$ & $\mathrm{~N}$ & $\mathrm{~N}$ & N & $\mathrm{N}$ & $\mathrm{N}$ & $\mathrm{N}$ & Y & Y & $N$ \\
\hline Ontario Governm & & & & & & & & & & & & \\
\hline 4. Buy from a foreign & $\mathrm{N}$ & $\mathrm{N}$ & N & $\mathrm{N}$ & Y & Y & Y & $\mathrm{N}$ & $\mathrm{N}$ & $N$ & Y & N \\
\hline 5. Buy from $A E C L$ & Y & $\mathrm{N}$ & Y & Y & $\mathrm{N}$ & N & $\mathrm{N}$ & $\mathrm{N}$ & $\mathrm{N}$ & N & N & Y \\
\hline State Number & 12 & 1 & 11 & 10 & 5 & 7 & 6 & 3 & 2 & 4 & 8 & 9 \\
\hline
\end{tabular}


for example, that state 11 has no unilateral improvement written below it for both FG and OG. Therefore, the state is rational (r) for each DM and constitutes an overall equilibrium (E). State 1 is sequentially stable (s) for FG since both of its unilateral improvements can be blocked by OG. In particular, if FG moves from state 1 to 3 , OG can then move from state 3 to 7 , which is less preferred to state 1 by FG. Likewise, if FG moves from state 1 to 2 , then $\mathrm{OG}$ can move from 2 to 6 , which is less preferred to state 1 by FG. Since both unilateral improvements by FG from state 1 can be blocked by OG, state 1 is sequentially stable (s) for FG. Moreover, because state 1 is rational ( $r$ ) for OG, it forms an overall equilibrium (E).

According to the definitions provided in the last section (Methods) regarding stability concepts, Nash and SEQ equilibria are found and shown in Table 10. State 1, where no DM takes any action, is one of the equilibria. This is a reasonable solution, since for a long time, the governments did not announce any specific decision. Although the Federal Government had announced the restructuring, as of May 2011, FG had not introduced the purchaser. The Ontario Government, on the other hand, has postponed its plan.

In the remaining part of this section and the next one, the states that could occur in 2008 and 2010 are designated by $A$ and $B$, respectively. In order to compare the equilibria of the 2008 and 2010 analyses, one should compare the results of the 2010 conflict:

- $(\mathrm{N} N \mathrm{~N}, \mathrm{~N} \mathrm{~N})$ : state B1, SEQ,

- (N Y N, N Y): state B11, Nash, GMR, SMR, SEQ.

with the results of 2008 :

- (N Y N, N N): state A3, GMR, SMR,

- (N Y N, Y N): state A7, Nash, GMR, SMR, SEQ.

Table 9 Reachable states

\begin{tabular}{lcc}
\hline State & FG & OG \\
\hline 1 & $2,3,4$ & 5,9 \\
\hline 2 & $1,3,4$ & 6,10 \\
\hline 3 & $1,2,4$ & 7,11 \\
\hline 4 & $1,2,3$ & 8,12 \\
\hline 5 & $6,7,8$ & 1,9 \\
\hline 6 & $5,7,8$ & 2,10 \\
\hline 7 & $5,6,8$ & 3,11 \\
\hline 8 & $5,6,7$ & 4,12 \\
\hline 9 & $10,11,12$ & 1,5 \\
\hline 10 & $9,11,12$ & 2,6 \\
\hline 11 & $9,10,12$ & 3,7 \\
\hline 12 & $9,10,11$ & 4,8 \\
\hline
\end{tabular}

Table 10 Stability analysis

\begin{tabular}{lcccccccccccc}
\hline Overall Equilibria & $\mathrm{E}$ & $\times$ & $\times$ & $\times$ & $\times$ & $\mathrm{E}$ & $\times$ & $\times$ & $\times$ & $\times$ & $\times$ & $\times$ \\
\hline Individual Stability & $\mathrm{r}$ & $\mathrm{u}$ & $\mathrm{u}$ & $\mathrm{r}$ & $\mathrm{s}$ & $\mathrm{s}$ & $\mathrm{s}$ & $\mathrm{r}$ & $\mathrm{u}$ & $\mathrm{u}$ & $\mathrm{u}$ & $\mathrm{u}$ \\
\hline FG State Ranking & 11 & 10 & 9 & 2 & 3 & 1 & 6 & 7 & 5 & 12 & 4 & 8 \\
\hline & 11 & 10 & & 2 & 3 & & 6 & 7 & 9 & 1 & 5 \\
\hline & & & 11 & & & 2 & & & 6 & 11 & 2 & 6 \\
\hline & & & & & & & & & & 10 & 3 & 7 \\
\hline Individual Stability & $\mathrm{r}$ & $\mathrm{r}$ & $\mathrm{r}$ & $\mathrm{r}$ & $\mathrm{s}$ & $\mathrm{u}$ & $\mathrm{u}$ & $\mathrm{u}$ & $\mathrm{u}$ & $\mathrm{u}$ & $\mathrm{u}$ & $\mathrm{u}$ \\
\hline OG State Ranking & 12 & 1 & 11 & 10 & 5 & 7 & 6 & 3 & 2 & 4 & 8 & 9 \\
\hline & & & & & 1 & 11 & 10 & 7 & 6 & 12 & 4 & 1 \\
\hline & & & & & & & & 11 & 10 & & 12 & 5
\end{tabular}

State B11 is a very strong equilibrium since it is Nash stable. This state is somewhat similar to state A7 in the 2008 analysis. State A7 is also Nash stable and is a stronger equilibrium than state A3. Therefore, the relationship between the results of the two conflicts can be listed below:

- States A1 and B1 constitute similar states which are the initial states of the 2008 and 2010 conflicts, respectively.

- State B2 (which is similar to A3) is a transition equilibrium in the 2010 conflict and the equilibrium of the 2008 conflict.

- State A7 or B11 are the strong equilibria in both conflicts.

Now the question that needs to be addressed is why is state A7 not the finishing point of the 2008 analysis? The answer is that state A7 (or B11) are actually the equilibria, but state A3 is a very considerable transition state. This nuclear conflict is very complicated since the DMs have changed their decisions on several occasions. That is why the conflict moved from state A7 to A3 in the 2008 conflict (Table 4).

\section{Status Quo analysis}

To investigate how the conflict evolves and moves from its 2008 state, state $\mathrm{A} 1$ or $\mathrm{B} 1$, to state B11, status quo analysis is performed. In a status quo analysis, one determines if a state of interest can be reached following a path from a starting or status quo state. The evolution of the conflict is shown in Table 11 .

State B2, which is equivalent to state A3, is the transition state. State A3 is the ending point of the 2008 conflict, but can be considered as a starting point of the 2010 conflict. The status quo table of the 2-DM 2008 conflict (Table 4) can be compared to Table 11. Although the initial state is shown to be state 1 in Table 11, this state is actually the very first point of the conflict in 2008. Therefore, state A1 is the initial state of the 2008 conflict, and state A3 (B2) is its ending. Finally, state 
B11 is the equilibrium in the 2010 game. The main reason for the difference between the two stages of the conflict (2008 and 2010) is the available information. Hence, one can understand how the changes in the situation over time can affect the final result.

\section{Attitude analysis}

Attitude analysis (Inohara et al., 2007; Bernath Walker et al. 2009) is another analysis that is performed on this conflict. In the original form of static analysis, each DM is considered to have a positive attitude towards him/ herself, and to be neutral towards other DMs. This means that each DM does not carry out an action that harms him/herself, but may move to a state that harms or benefits other DMs. The way DMs' attitudes can be shown is indicated in Table 12 . The symbol eij $\in\{-, 0,+\}$, $\mathrm{i}, \mathrm{j}=1, \ldots, \mathrm{n}$, where $\mathrm{n}$ is the number of players, denotes the attitude of player $i$ towards player $j . e_{i j}=-, e_{i j}=0$, $\mathrm{e}_{\mathrm{ij}}=+$ indicate negative, neutral, and positive attitudes towards the opponent, respectively. Table 12 also shows the attitudes of players in the original form of static analysis.

It is worth noting that the analysis that is shown in Table 10 is performed by taking into consideration the attitude set indicated in Table 12 . However, another set of attitudes may be assumed in this game. Two different governments constitute the DMs in this conflict. The Federal Government is run by the Conservative Party of Canada, and the Ontario Government is run by the Liberal Party. Therefore, aside from the situation of the Ontario contract and the future of AECL, the game involves the political conflicts between these two politically opposed DMs. According to the background of the conflict, after the Ontario Government announced that it favoured AECL's proposal, the Federal Government announced the restructuring of the company. The implementation of a new nuclear station in Ontario is a vital requirement for the province. However, although the Federal Government is keen on being a pioneer in

Table 11 Evolution of 2010 conflict

\begin{tabular}{llllllll}
\hline Federal Government & & & & & & \\
\hline 1. Sell AECL to a foreign company & $\mathrm{N}$ & $\mathrm{FG}$ & $\mathrm{Y}$ & & $\mathrm{Y}$ & $\mathrm{FG}$ & $\mathrm{N}$ \\
\hline 2. Sell AECL to a Canadian company & $\mathrm{N}$ & & $\mathrm{N}$ & & $\mathrm{N}$ & $\mathrm{FG}$ & $\mathrm{Y}$ \\
\hline 3. Support AECL & & $\mathrm{N}$ & $\mathrm{N}$ & & $\mathrm{N}$ & & $\mathrm{N}$ \\
\hline Ontario Government & & & & & & & \\
\hline 4. Buy from a foreign company & $\mathrm{N}$ & $\mathrm{N}$ & & $\mathrm{N}$ & & $\mathrm{N}$ \\
\hline 5. Buy from AECL & $\mathrm{N}$ & $\mathrm{N}$ & $\mathrm{OG}$ & $\mathrm{Y}$ & & $\mathrm{Y}$ \\
& & & & $\rightarrow$ & & & \\
\hline
\end{tabular}

Table 12 Tabular representation of attitudes in a regular 2-DM game

\begin{tabular}{lcc}
\hline & Player 1 & Player 2 \\
\hline Player 1 & $e_{11}=+$ & $e_{21}=0$ \\
\hline Player 2 & $e_{21}=0$ & $e_{22}=+$ \\
\hline
\end{tabular}

nuclear technology, it seems that it does not have a plan to help Ontario in this matter, and this may be the reason for the political conflicts. Therefore, a new attitude arrangement (Table 13) is considered, and a new static analysis is performed (Table 14). According to the attitudes in Table 12, from each state, FG can move to a state among the reachable states that is less preferred by OG and more preferred by itself. OG can move to the states that are more preferred by itself, ignoring FG's preference. The corresponding unilateral moves to each state are indicated below the ranking of states for each DM in Table 14.

With the new set of attitudes, three states are found as the equilibria of the conflict, states 4,10 , and 11. State 10 represents the situation in which FG sells AECL to a foreign company, and OG buys reactors from AECL. State 4 is a state in which the Federal Government supports AECL, and the Ontario Government decides not to buy any new reactor. State 11 represents the situation in which FG sells AECL to a domestic company, and OG buys reactors from AECL. The results show that if, in reality, the Federal Government has the intention of harming the Ontario Government, and at the same time, benefitting itself, it is possible that the final outcome of the game is state 4, which is among the least preferred states for both DMs.

\section{Conclusions}

The dispute over the expansion of the Darlington nuclear site in Ontario is formally studied in this paper for two different points in time: the fall of 2008 and spring of 2010. According to the background information about this conflict in 2008, four DMs were considered to be involved in the game: the Federal and Ontario Governments, AECL, and green groups. However, after several sensitivity analyses, the authors arrived at the conclusion that the key DMs are the Federal and Ontario Governments. The status quo analysis is also provided and the evolution of the conflict from March to fall 2008 is explained. The conflict did not terminate at this point and is still ongoing. The results and information of the

\section{Table 13 Attitudes in the new analysis}

\begin{tabular}{llc}
\hline & FG & OG \\
\hline FG & $e_{11}=+$ & $e_{12}=0$ \\
\hline OG & $e_{21}=-$ & $e_{22}=+$ \\
\hline
\end{tabular}


Table 14 Stability Analysis $\left(e_{11}=e_{22}=+, e_{12}=-, e_{21}=0\right)$

\begin{tabular}{lcccccccccccc}
\hline Overall Equilibria & $E$ & $E$ & $\times$ & $\times$ & $\times$ & $\times$ & $\times$ & $\times$ & $\times$ & $\times$ & $E$ & $\times$ \\
\hline Individual Stability & $r$ & $r$ & $r$ & $r$ & $s$ & $u$ & $r$ & $u$ & $u$ & $u$ & $r$ & $r$ \\
\hline FG State Ranking & 11 & 10 & 9 & 2 & 3 & 1 & 6 & 7 & 5 & 12 & 4 & 8 \\
\hline & & & & & 2 & 3 & & 6 & 7 & 9 & \\
\hline
\end{tabular}

\begin{tabular}{llllllllllllll}
\hline Individual Stability & $r$ & $r$ & $r$ & $r$ & $s$ & $u$ & $u$ & $u$ & $u$ & $r$ & $u$ & $u$
\end{tabular}

\begin{tabular}{lllllllllll}
\hline & 1 & 11 & 10 & 7 & 6 & 12 & 4 & 1 \\
\hline
\end{tabular}

$\begin{array}{llll}11 & 10 & 12 & 5\end{array}$

analysis in 2008, and an updated background in 2010, are used to perform another analysis in 2010. Only the two governments are counted as the main DMs at this time, and their options have changed from the situation in 2008. The equilibria found in this analysis for 2010 suggest that the conflict will ultimately move to a state in which the Federal Government sells AECL to a domestic company, and the Ontario Government buys its reactors from AECL or its new CANDU owner. The other outcome is the initial state, in which no DM takes any action. This state actually was stable in reality for a period of time. So far, the results are closely correlated with what happened in reality, as the Federal Government sold AECL to SNC-Lavalin, a Canadian company (Babbage, 2011; McCarthy, 2011). The decision of the Ontario Government is still unknown, but the analyses suggest that Ontario will buy its reactors from AECL. In addition, in the attitude analysis, it is discovered that if the Federal Government has a negative attitude towards the Ontario Government, it is possible that the final outcome is a state that is among the least preferred states for both DMs.

\section{Methods}

The Graph Model for Conflict Resolution (GMCR) is the approach that is used to analyze this conflict. The GMCR methodology was developed by Fang et al. (1993) based upon earlier work by Fraser and Hipel (1984) and Howard (1971). This decision technology can be used to analyze disputes among different parties with different options or decision choices, and different preferences or value systems. It is for this reason that this methodology has been chosen to be used in this research. GMCR constitutes a flexible approach to the representation, analysis, and understanding of a strategic conflict. It also facilitates modifications to the way in which the conflict is represented, thereby supporting sensitivity and what-if analyses. Finally, descriptions and comparisons of a range of different approaches for formally studying conflict are provided in two books edited by Hipel (2009a,b).
GMCR is able to provide a DM with suggestions for reaching possible resolutions either independently or in cooperation with others. In some cases, win/win resolutions can be reached even though this may initially appear to be difficult to achieve. Figure 1 illustrates the way in which a conflict study is carried out in practice. GMCR, along with its associated decision support system GMCR II (Fang et al., 2003a,b; Hipel et al., 1997), is used to model the conflict and analyze the current situation.

The most important part of applying the GMCR model to a real-world conflict is the background investigation. Searching the news, talking to experts, and reading the related published articles help the analyst acquire a proper understanding of a conflict and develop a realistic model. Therefore, accurate and comprehensive information plays a fundamental role. In fact, the whole "Modeling" section, as shown in Figure 1, as well as the "Interpretation and Sensitivity" stage in the "Analysis" part, directly depends on the analyst's findings. In other words, the analyst determines the DMs, their options, infeasible states, and relative preferences. The analyst's

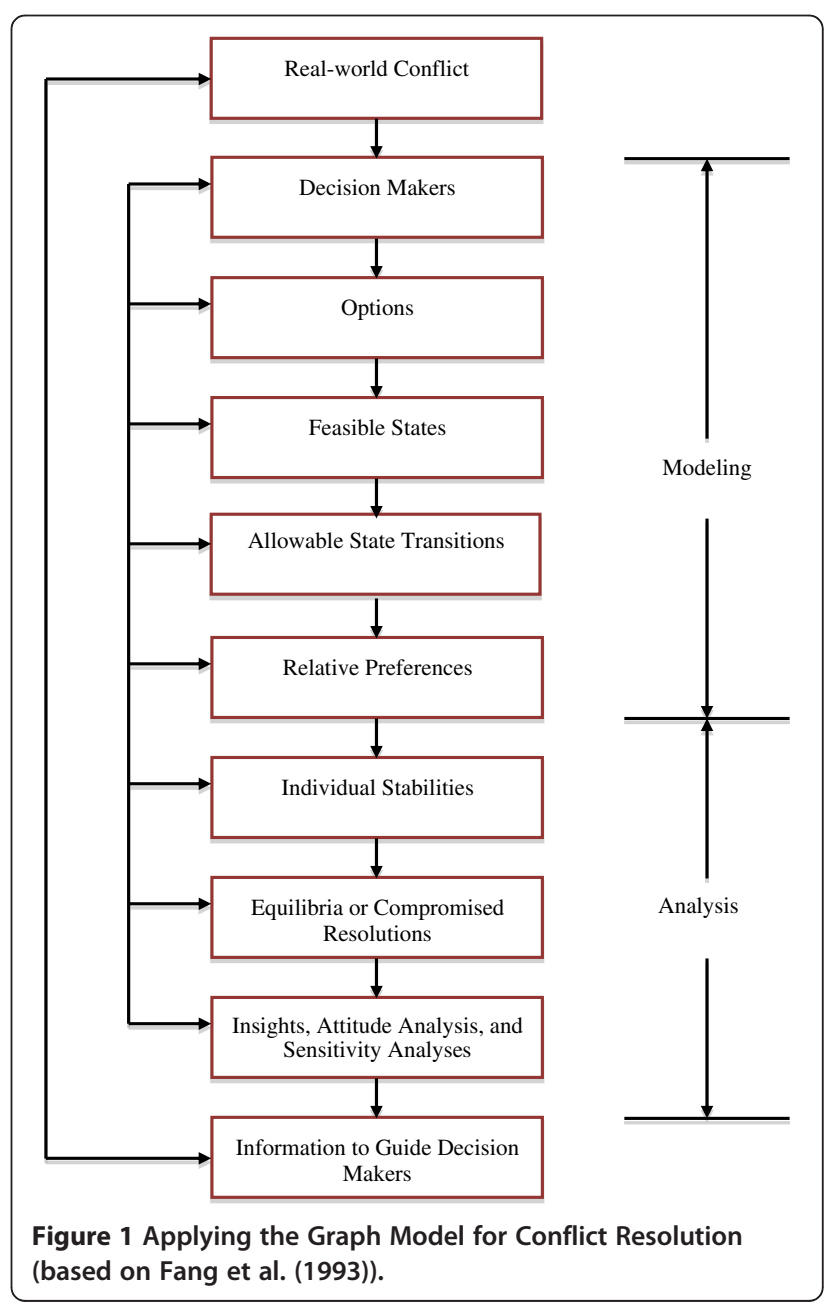


decision about executing different sensitivity analyses, and the interpretations and suggestions to actual DMs for an ongoing conflict depend on the available data. In some cases, the analyst may work directly with a DM or the DM's representative involved in a dispute, while in other situations, he or she may be working with an interested stakeholder who has no direct decision-making power in influencing the dispute under study but is affected by its outcome.

\section{Decision makers, options, feasible states, and allowable state transitions}

To use the graph model methodology, one must first model the dispute in terms of the DMs. A DM is a person or a group who plays a role in a conflict and has one or more decisions to make, or alternatives to choose. Besides the DMs and options, states should be defined. A state is any combination of chosen options. A sample state, under the name of Status Quo, is shown in Table 1. The letter "Y" means that the DM selects an option under its control, while " $\mathrm{N}$ " denotes the refusal of a DM to choose the option. A dash ("-") indicates that for the DM to choose or not to choose an option is inconsequential. Some states cannot occur in reality. These states are considered "infeasible" and have to be removed from the conflict.

After determining the feasible states, the allowable transitions should be determined. From each state, a specific DM can only move to a certain set of states. This set, which is referred to as a DM's Reachable List, consists of the states in which other DMs' choices, including $\mathrm{Y}, \mathrm{N}$, or -, are not different from the initial state. When a DM on his/her own moves from one state to another, this move is called a unilateral move. If the state to which the DM moves to is more preferred by him or her, the move is called a "unilateral improvement".

\section{Relative preferences and static analysis}

After generating a complete set of feasible states, the analyst must determine the relative preferences, in which, for each DM, states are ranked from most to least preferred, where ties are allowed. Three methods can be used in GMCR II to define the relative preferences of each DM: Direct Ranking, Option Weighting, and Option Prioritizing.

Subsequently, according to a rich range of solution concepts describing how people or organizations may behave under conflict, a stability analysis of the conflict is carried out to calculate the stable states for each DM. A state that is stable for all DMs in the dispute is called an equilibrium, which suggests a possible resolution to the conflict.

A range of stability definitions have been defined for determining stable states in a dispute in which it is not advantageous for a DM to move away from a state under study. The four useful stability definitions given in Table 15 consist of Nash (Nash, 1950, 1951), sequential (Fraser and Hipel, 1984), general metarationality (GMR) (Howard, 1971), and symmetric metarationality (SMR) (Howard, 1971). Qualitative explanations of how each stability definition works along with its overall characteristics are provided in Table 15, while Fang et al. (1993) furnish mathematical definitions within the paradigm of GMCR. When a state is stable for all of the DMs according to a specific stability definition, the state constitutes an equilibrium or possible compromise resolution.

\section{Interpretation and sensitivity analysis}

After carrying out a stability analysis, one may perform appropriate sensitivity analyses. In this case, the DMs, the options, or the relative preferences can be changed to obtain a better understanding of the issue and ascertain how the equilibrium results are affected.

There are also other types of analyses that can be carried out within the GMCR framework to interpret the results, including attitudes (Inohara et al., 2007; Bernath Walker et al. 2009), coalitions (Kilgour et al., 2001; Inohara and Hipel, 2008a,b), strength of preference (Hamouda et al., 2004, 2006; Xu et al., 2009a), misperceptions (called hypergames) (Wang et al., 1988), emotions (Obeidi et al., 2005, 2006, 2009a, 2009b), preference uncertainty (Li et al., 2004; Hipel et al., 2011),

Table 15 Solution concepts and human behaviour (Fang et al., 1993; Hipel et al., 1997)

\begin{tabular}{|c|c|c|c|c|c|}
\hline $\begin{array}{l}\text { Solution } \\
\text { Concept }\end{array}$ & Stability Description & Foresight & $\begin{array}{l}\text { Knowledge } \\
\text { of Preference }\end{array}$ & Disimprovement & $\begin{array}{l}\text { Strategic } \\
\text { Risk }\end{array}$ \\
\hline Nash & $\begin{array}{l}\text { DM cannot move unilaterally } \\
\text { to a more preferred state }\end{array}$ & Low & Own & Never & Ignores risk \\
\hline SEQ & $\begin{array}{l}\text { All DM's unilateral improvements } \\
\text { are sanctioned by subsequent } \\
\text { unilateral improvements by others }\end{array}$ & Medium & All & Never & Takes some risks \\
\hline GMR & $\begin{array}{l}\text { All DM's unilateral Improvements } \\
\text { are sanctioned by subsequent } \\
\text { unilateral moves by others }\end{array}$ & Medium & Own & By opponent & Avoids risks \\
\hline SMR & $\begin{array}{l}\text { All DM's unilateral improvements } \\
\text { are sanctioned, even after response by the DM }\end{array}$ & Medium & Own & By opponent & Avoids risks \\
\hline
\end{tabular}


conflict dynamics (Li et al., 2005), and matrix stability calculations (Xu et al., 2009b). By applying different analyses, the outcomes can be more deeply interpreted and additional strategic insights may be achieved.

\section{Endnotes}

${ }^{a}$ After NRU restarted in January 2008, another shutdown happened in 2009. On May 14, 2009, NRU was shut down due to a loss of electrical power in Ontario. On May 15, when the experts were investigating the reactor, they observed a small leak of heavy water within the facility. Therefore, the NRU was kept out of service for repair (AECL, 2009). On August 17, 2010, the NRU was returned to operation (NRU Canada, 2010). The performance of NRU, as an important supplier of medical isotopes in the world, is critical, and the repeated shutdowns of this reactor diminished the reputation of AECL, the company responsible for it.

\section{Abbreviations}

AECL: Atomic Energy of Canada Limited; GMCR: Graph Model for Conflict Resolution; DM: Decision Maker; CANDU: CANada Deuterium Uranium; ACR: Advanced CANDU Reactors; OPG: Ontario Power Generation; R\&D: Research and Development; CIGI: Centre for International Governance Innovation; RFP: Request For Proposal; GG: Green Groups; OG: Ontario Government; FG: Federal Government; DUPIC: Direct Use of spent Pressurized water reactor fuel In CANDUs; GMR: General Metarationality; SMR: Symmetric Metarationality; SEQ: Sequential Stability; NDP: New Democratic Party; MAPLE: Multipurpose Applied Physics Lattice Experiment.

\section{Competing interests}

The authors declare that they have no competing interests.

\section{Authors' contributions}

MA modeled the conflict and performed the analysis. KWH and MD revised the manuscript critically for important intellectual content and improved the paper by their important comments and guidance. All authors read and approved the final manuscript.

\section{Author details \\ ${ }^{1}$ Department of Systems Design Engineering, University of Waterloo, Waterloo, Ontario N2L3G1, Canada. ${ }^{2}$ Centre for International Governance Innovation, Waterloo, Ontario N2L 6C2, Canada. ${ }^{3}$ School of Business and Economics, Wilfrid Laurier University, Waterloo, Ontario N2L3C5, Canada.}

Received: 13 September 2012 Accepted: 20 September 2012

Published: 29 October 2012

\section{References}

AECL (2008) CANDU Reactors. http://www.aecl.ca/Reactors/CANDU6.htm. Accessed September 25, 2008

AECL (2009) Restarting Safely, Reassuring Canadians. http://www.nrucanada.ca/ en/home/projectrestart/NRUOutage.aspx. Accessed December 8, 2010

Akin D (2008) Over Budget and Behind Schedule, Reactor Replacement Axed. http://www.canada.com/topics/news/story.html?id=ba8921b1-5d42-4122983e-3e0a3008ccea. Accessed October 20, 2008

Babbage M (2011) AECL sold to SNC-Lavalin Group for \$15M. http://www.citytv. com/toronto/citynews/life/money/article/139957-aecl-sold-to-snc-lavalin group-for-15m. Accessed July 17, 2011

Benzie R, Black D (2008) Darlington to Get 2 New Reactors. http://www.thestar. com/News/Ontario/article/444474. Accessed October 10, 2008

Bernath Walker S, Hipel KW, Inohara T (2009) Strategic Decision Making for Improved Environmental Security: Coalitions and Attitudes in the Graph Model for Conflict Resolution. J Syst Sci Syst Eng 18(4):461-476
Cadham J (2009) The Canadian Nuclear Industry: Status and Prospects. http://www.cigionline.org/publications/2009/11/canadian-nuclear-industrystatus-and-prospects. Accessed Sep 16, 2011

Canadian Nuclear Safety Commission (2011) Is our energy superpower vision slipping away?. http://nuclearsafety.gc.ca/eng/mediacentre/updates/march11-2011-japan-earthquake-comparison-candu-and-bwr-reactors.cfm. Accessed April 4, 2011

CBC News (2006) McGuinty Takes Blame for Broken Promise on Coal plant Closures. http://www.cbc.ca/canada/toronto/story/2006/11/16/coalresponsibility.html. Accessed September 15, 2008

CBC News (2008) Nuclear Safety Watchdog Head Fired for "Lack of Leadership": Minister. http://www.cbc.ca/canada/story/2008/01/16/keen-firing.html. Accessed December 8, 2008

CBC News (2009) Canada Eyes Sale of Stake in AECL Reactor Business. http://www.cbc.ca/money/story/2009/05/28/aecl-future-sale.html. Accessed December 8, 2010

CTV (2009) Feds Announce Major Shakeup of Nuclear Agency. http://www.ctv.ca/servlet/ArticleNews/story/CTVNews/20090528/AECL Ishakeup $\backslash 090528 / 20090528$ ?hub=Canada. Accessed December 8, 2010

Fang L, Hipel KW, Kilgour DM (1993) Interactive Decision Making. Wiley, New York

Fang L, Hipel KW, Kilgour DM, Peng X (2003a) A Decision Support System for Interactive Decision Making, Part 1: Model Formulation. IEEE T Syst Man Cy C 33(1):42-55

Fang L, Hipel KW, Kilgour DM, Peng X (2003b) A Decision Support System for Interactive Decision Making, Part 2: Analysis and Output Interpretation. IEEE T Syst Man Cy C 33(1):56-66

Frame A (2008) A Very Political Power Play. http://www.thestar.com/comment/ Columnist/article/349255. Accessed September 20, 2008

Fraser NM, Hipel KW (1984) Conflict Analysis. Models and Resolutions, Elsevier, New York

Geddes J (2007) Harper Embraces the Nuclear Future. http://www.macleans.ca/ canada/features/article.jsp?content $=20070507 \backslash 105095 \backslash 105095$. Accessed October 25, 2008

Goodhand P, Drouin R, Mason T, Turcotte E (2009) Report of the Expert Review Panel on Medical Isotope Production. Minister of Natural Resources, Ottawa, Canada, http://www.marketwire.com/press-release/Natural-Resources-CanadaExpert-Panel-Delivers-Report-on-Isotopes-1085758.htm. Accessed December 20, 2010

Hamilton T (2007) Could Reactors Withstand Blast? Report That Regulator Will Impose New Safety Standards May Pose a Big Hurdle for AECL Nuclear Sale in Ontario. http://pqasb.pqarchiver.com/thestar/access/1196866631.html? FMT $=$ ABS\&FMTS=ABS:FT\&type $=$ current $\&$ date $=$ Jan $+19,+2007 \&$ author $=$ Tyler + Hamilton\&pub=Toronto+Star\&edition $=\&$ startpage $=$ F.1\&desc $=$ Could +reactors+withstand+blast. Accessed October 25, 2008

Hamilton T (2008a) A Chance for Nuclear Industry to Clean up Its Act. http://www.thestar.com/article/293658. Accessed September 23, 2008

Hamilton T (2008b) AECL Failed to Disclose Loss of Radioactive Part: Report. http://www.thestar.com/News/Ontario/article/467742. Accessed October 20 2008

Hamouda L, Kilgour DM, Hipel KW (2004) Strength of Preference in the Graph Model for Conflict Resolution. Group Decis Negot 13:449-462

Hamouda L, Kilgour DM, Hipel KW (2006) Strength of Preference in Graph Models for Multiple Decision-maker Conflicts. Appl Math Comput 179(1):314-327

Harris J (2008) Nuclear power: Expensive, Irresponsible and Unnecessary. http://www.greenparty.ca/en/node/4218. Accessed September 25, 2008

Hipel KW (ed) (2009a) Conflict Resolution, Volume 1. Eolss Publishers, Oxford, United Kingdom, ISBN-978-1-84826-120-4 (Adobe e-Book), ISBN-978-1-84826-570-7 Library Edition (Hard Cover)

Hipel KW (ed) (2009b) Conflict Resolution, Volume 2. Eolss Publishers, Oxford, United Kingdom, ISBN-978-1-84826-121-1 (Adobe e-Book) ISBN-978-1-84826-571-4 Library Edition (Hard Cover)

Hipel KW, Bowman C (2011) Is our energy superpower vision slipping away? Toronto Star, March 16, 2011. http://www.thestar.com/opinion/ editorialopinion/article/955245-is-our-energy-superpower-vision-slippingaway. Accessed April 4, 2011

Hipel KW, Kilgour DM, Bashar MA (2011) Fuzzy Preferences in Multiple Participant Decision Making. Scientia Iranica, Transactions D: Computer Science \& Engineering and Electrical Engineering, special publication dedicated to the lifelong achievements of Professor Lotfi A Zadeh 18(3):627-638 
Hipel KW, Kilgour DM, Fang L, Peng X (1997) The Decision Support System GMCR in Environmental Conflict Management. Appl Math Comput 83(2 and 3):117-152

Howard N (1971) Paradoxes of Rationality: Theory of Metagame and Political Behaviour. MIT Press, Cambridge, MA

Inohara T, Hipel KW (2008a) Coalition Analysis in the Graph Model for Conflict Resolution. Syst Eng 11(4):343-359

Inohara T, Hipel KW (2008b) Interrelationships among Noncooperative and Coalition Stability Concepts. J Syst Sci Syst Eng 17(1):1-29

Inohara T, Hipel KW, Walker S (2007) Conflict Analysis Approaches or Investigating Attitudes and Misperceptions in the War of 1812. J Syst Sci Syst Eng 16(2):181-201

Kilgour DM, Hipel KW, Fang L, Peng X (2001) Coalition Analysis in Group Decision Support. Group Decis Negot 10(2):159-175

Li KW, Hipel KW, Kilgour DM, Fang L (2004) Preference Uncertainty in the Graph Model for Conflict Resolution. IEEE T Syst Man Cy A 34(4):507-520

Li KW, Kilgour DM, Hipel KW (2005) Preference Uncertainty in the Graph Model for Conflict Resolution. J Oper Res Soc 5:699-707

McCarthy S (2010) Ottawa's plan to sell AECL threatens future of Canada's nuclear industry. http://www.theglobeandmail.com/report-on-business/ industry-news/energy-and-resources/ottawas-plan-to-sell-aecl-threatensfuture-of-canadas-nuclear-industry/article1792762/. Accessed December 7, 2010

McCarthy S, Howlett K (2009) AECL's Future in Doubt as Ontario Suspends Nuclear Power Plans. http://www.theglobeandmail.com/news/national/ ontario-suspends-nuclear-power-plans/article1200469/. Accessed December 8, 2010

McCarthy S (2011) Ottawa to sell AECL to SNC-Lavalin. http://www.theglobeandmail.com/report-on-business/ottawa-to-sell-aecl-tosnc-lavalin/article2078110/. Accessed July 18, 2011

McParland K (2008) Dalton McGuinty's Opportunity to Slash Verbal Gas Emissions. http://network.nationalpost.com/np/blogs/posted/archive/2008/03/26/ dalton-mcguinty-s-opportunity-to-slash-verbal-gas-emissions.aspx (September 25, 2008)

Nash JF (1950) Equilibrium Points in N-player Games. Proc Natl Acad Sci 36(1):48-49

Nash JF (1951) Non-cooperative Games. Ann Math 54(2):286-295

Nathwani J (2009) Canada's Medical Isotope Crisis: A Way Forward. J Policy Engagement 1(4):12-13, Available at www.ocepp.ca

New Democratic Party (2008) NDP Platform. http://www.ndp.ca/platform/ environment/newenergyeconomy. Accessed October 17, 2008

NRU Canada (2010) Delivering on Our Commitment to Restart. http://www.nrucanada.ca/en/home/default.aspx. Accessed December 1, 2010

Obeidi A, Hipel KW, Kilgour DM (2005) The Role of Emotions in Envisioning Outcomes in Conflict Analysis. Group Decis Negot 14(6):481-500

Obeidi A, Hipel KW, Kilgour DM (2006) Turbulence in Miramichi Bay: The Burnt Church Conflict over Native Fishing Rights. J Am Water Resour Assoc 42(12):1629-1645

Obeidi A, Kilgour DM, Hipel KW (2009a) Perceptual Graph Model Systems. Group Decis Negot 18(3):261-277

Obeidi A, Kilgour DM, Hipel KW (2009b) Perceptual Stability Analysis of a Graph Model System. IEEE T Syst Man Cy A 39(5):993-1006

Ontario Government (2009) Nuclear Procurement Project Update. http://www.news.ontario.ca/mei/en/2009/06/nuclear-procurement-projectupdate.html. Accessed July 19, 2009

Ontario Government (2010) Ontario's Long-term Energy Plan. http://www.mei.gov.on.ca/en/energy/. Accessed December 7, 2010

Puxley C (2007) Sale of Canada's Nuclear Giant Shouldn't be Negotiated in Private: Lib- erals. http://energyquest4nanticoke.ca/nukegiant.htm. Accessed November 28, 2008

Sierraclub (2008) Towards a Nuclear-Free Canada. http://www.sierraclub.ca/national/programs/atmosphere-energy/nuclear-free/ index.shtml Accessed September 23, 2008

Spears T (2008) Reactor Connected to Second Safety Pump. http://www.canada.com/topics/news/national/story.html?id=0e63c2ea-fd594a80-b047-b3880f30c729. Accessed November 5, 2008

The Globe and Mail (2010) New Brunswick throws a wrench into AECL sale plans. http://www.nuclearcounterfeit.com/?p=3445. Accessed December 7, 2010

The Star (2009) Privatization of AECL Radioactive Issue for Ottawa. http://www.thestar.com/Opinion/article/612823. Accessed December 20, 2010
Wang M, Hipel KW, Fraser NM (1988) Modeling Misperceptions in Games. Behav Sci 33(3):207-223

Xu H, Hipel KW, Kilgour DM (2009a) Multiple Levels of Preference in Interactive Strategic Decisions. Discret Appl Math 157(15):3300-3313

Xu H, Hipel KW, Kilgour DM (2009b) Matrix Representation of Solution Concepts in Multiple Decision Maker Graph Models. IEEE T Syst Man Cy A 39(1):96-108

doi:10.1186/2193-2697-1-11

Cite this article as: Armin et al:: The Ontario nuclear power dispute: a strategic analysis. Environmental Systems Research 2012 1:11.

\section{Submit your manuscript to a SpringerOpen ${ }^{\circ}$ journal and benefit from:}

- Convenient online submission

- Rigorous peer review

- Immediate publication on acceptance

- Open access: articles freely available online

- High visibility within the field

- Retaining the copyright to your article

Submit your next manuscript at $>$ springeropen.com 